\title{
Reduced Stathmin-1 Expression in Natural Killer Cells Associated with Spontaneous Abortion
}

\author{
Yi Lin, ${ }^{\star}$ Cui Li, ${ }^{\dagger}$ Bin Shan, ${ }^{\ddagger}$ Wenjing Wang, ${ }^{\S}$ \\ Shigeru Saito, ${ }^{\natural}$ Jiehan $\mathrm{Xu},{ }^{*}$ Jingfang $\mathrm{Di},{ }^{\S}$ \\ Yanmin Zhong, ${ }^{\S}$ and Da-Jin Li ${ }^{\| * *}$ \\ From the Department of Obstetrics and Gynecology," Institute of \\ Obstetrics and Gynecology, Renji Hospital, School of Medicine, \\ Shanghai Jiaotong University, Shanghai; the Key Laboratory of \\ Cancer Proteomics of Chinese Ministry of Health ${ }^{\dagger}{ }^{\top}$ Xiangya \\ Hospital, Central South University, Changsha, Hunan, China; the \\ Department of Medicine, ${ }^{\ddagger}$ Tulane University Health Sciences \\ Center, New Orleans, Louisiana; the Institute of Tissue \\ Transplantation and Immunology, ${ }^{\S}$ College of Life Science and \\ Technology, Jinan University, Guangzhou, China; the \\ Department of Obstetrics and Gynecology, "Taculty of Medicine, \\ University of Toyama, Toyama, Japan; the Laboratory for \\ Reproductive Immunology," Hospital and Institute of Obstetrics \\ and Gynecology, Fudan University Shanghai Medical College, \\ Shanghai, China; and the Department of Obstetrics and \\ Gynecology,* Hainan Medical College Affiliated Hospital, \\ Haikou, Hainan, China
}

Female CBA/J mice impregnated by male DBA/2J mice $(\mathrm{CBA} / \mathrm{J} \times \mathrm{DBA} / 2 \mathrm{~J}$ matings) are prone to spontaneous abortion, although the reason for this is unclear. In this study, the stathmin-1 expression pattern was evaluated in uterine natural killer ( $\mathrm{UNK}$ ) cells purified from $\mathrm{CBA} / \mathrm{J} \times \mathrm{DBA} / 2 \mathrm{~J}$ matings. Results were compared with those in a $\mathbf{C B A} / \mathrm{J} \times \mathbf{B A L B} / \mathbf{c}$ control group that yields successful pregnancies. The mean \pm SD percentage of stathmin- $1^{+}$cells in the $\mathrm{CD} 49 \mathrm{~b}^{+}$uNK cell population was lower in $\mathbf{C B A} / \mathrm{J} \times \mathrm{DBA} / 2 \mathrm{~J}$ mice $(0.7 \% \pm$ $0.4 \%)$ than in control $\mathbf{C B A} / \mathrm{J} \times \mathbf{B A L B} / \mathrm{c}$ mice $(4.9 \% \pm$ $1.5 \%, P<0.01)$ using flow cytometry, and the intracellular stathmin-1 level in uNK cells was lower in $\mathrm{CBA} / \mathrm{J} \times \mathrm{DBA} / 2 \mathrm{~J}$ mice than in control mice using Western blot analysis. Co-localization of lectin from Dolichos biflorus agglutinin (DBA-lectin) and stathmin-1 was confirmed using multivision immunohistochemical analysis. The frequency of stathmin- ${ }^{+}$DBA-lec$\operatorname{tin}^{+}$cells was lower in $\mathbf{C B A} / \mathrm{J} \times \mathrm{DBA} / 2 \mathrm{~J}$ mice than in $\mathrm{CBA} / \mathrm{J} \times \mathrm{BALB} / \mathrm{c}$ mice. A similar trend in the frequency of stathmin- $1^{+} \mathrm{CD} 56^{+}$cells was seen in patients with unexplained spontaneous abortion compared with normal early pregnancy. A neutralizing antibody against stathmin-1 further increased the percentage of embryo loss in $\mathrm{CBA} / \mathrm{J} \times \mathrm{DBA} / 2 \mathrm{~J}$ matings. These results provide evidence that stathmin- 1 expression in uNK cells at the maternal-fetal interface may help modulate uNK cell function and may be beneficial for a successful pregnancy. (Am J Patbol 2011, 178:506-514; DOI: 10.1016/j.ajpath.2010.10.005)

Stathmin-1 is a small (19-kDa) regulatory phosphoprotein that integrates diverse intracellular signaling pathways. It is highly conserved among vertebrates and is associated with tubulin binding and microtubule destabilization. ${ }^{1,2}$ Stathmin-1 has a complex phosphorylation pattern in response to various extracellular signals, in particular growth and differentiation factors. ${ }^{3}$ Moreover, stathmin-1 phosphorylation varies during the cell cycle. ${ }^{4}$ It has thus been thought that stathmin-1 can act as a relay integrating the activation of diverse intracellular signaling pathways and mediating the control of cell proliferation, differentiation, and other functions. ${ }^{5}$

Stathmin-1 protein and mRNA were previously shown to be expressed in the pregnant uterus and decidualizing endometrial stromal cells in human and murine models. ${ }^{6-8}$ Furthermore, stathmin-1 is up-regulated in rodent uteri at the site of embryo implantation and is highly

Supported by the National Natural Science Foundation of China (30730087, 30872761, and 30972970), the National Basic Research Program of China (2006CB944007), the Program for New Century Excellent Talents in University (NCET-07-0861), the Focus Construction Subject of Shanghai Education Department, the New Cutting-Edge Technology Project (SHDC12010122), a grant from the Ministry of Education, Culture, Sports, Science and Technology, Japan (Grant-in-Aid for Scientific Research [B] - 20390431), and grants from the Ministry of Health Labour and Welfare, Japan (Health Labour Sciences Research grant H2O-kodomoippan-002).

Y.L., C.L., and B.S. contributed equally to this work.

Accepted for publication October 4, 2010.

Address reprint requests to Yi Lin, M.D., Department of Obstetrics and Gynecology, Institute of Obstetrics and Gynecology. Renji Hospital, School of Medicine, Shanghai Jiaotong University, Shanghai. 200001, China; or Da-Jin Li, M.D., Laboratory for Reproductive Immunology, Hospital and Institute of Obstetrics and Gynecology, Fudan University Shanghai Medical College, Shanghai, 200011, China. E-mail: yilinonline@gmail.com or djli@ shmu.edu.cn. 
expressed in the decidual zone during the decidualization process. ${ }^{7,8}$ These results suggest that stathmin-1 may participate in the modulation of embryo implantation and decidualization.

Female CBA/J mice impregnated by male DBA/2J mice (CBA/J $\times D B A / 2 J$ matings) are prone to abortion, in contrast to the major histocompatibility complex-identical $\mathrm{CBA} / \mathrm{J} \times \mathrm{BALB} / \mathrm{c}$ matings, which are resistant to abortion. ${ }^{9}$ The underlying mechanisms for these observations are unclear. Clark and colleagues ${ }^{9}$ suggested that endothelium is the primary effector cell population, and this was supported by a recent work using CBA/J×DBA/2J matings. ${ }^{10}$ Notably, inhibition of natural killer (NK) cells using anti-asialo GM1 antiserum significantly decreased the resorption rate of embryos in $\mathrm{CBA} / \mathrm{J} \times \mathrm{DBA} / 2 \mathrm{~J}$ matings. ${ }^{9}$ In the present study, uterine NK (UNK) cells were purified from $\mathrm{CBA} / \mathrm{J} \times \mathrm{DBA} / 2 \mathrm{~J}$ and $\mathrm{CBA} / \mathrm{J} \times \mathrm{BALB} / \mathrm{C}$ allogeneic pregnant models using magnetic affinity cell sorting (MACS). The percentage of stathmin- $1^{+}$cells in the UNK cell population was determined using flow cytometry, and the stathmin-1 protein expression level in uNK cells was determined using two-dimensional gel electrophoresis (2-DE), mass spectrometry (MS), and Western blot analysis. Multivision immunohistochemical analysis $(\mathrm{IHC})$ was used to examine the distribution patterns of stathmin-1 ${ }^{+}$ cells in the uteri of pregnant female mice and in firsttrimester human decidual tissue. In addition, inhibition of stathmin-1 was performed in $\mathrm{CBA} / \mathrm{J} \times \mathrm{DBA} / 2 \mathrm{~J}, \mathrm{CBA} /$ $\mathrm{J} \times \mathrm{BALB} / \mathrm{C}$, and $\mathrm{CBA} / \mathrm{J} \times \mathrm{CBA} / \mathrm{J}$ mice. From these data, the possible role of stathmin-1 in allogeneic pregnancy tolerance was investigated.

\section{Materials and Methods}

\section{Pregnant Models of CBA/J $\times D B A / 2 J$, $C B A / J \times B A L B / C$, and $C B A / J \times C B A / J$ Matings}

Female CBA/J mice and male CBA/J, DBA/2J, and BALB/c mice (8 to 12 weeks old) were purchased from the Model Animal Center of Nanjing University (Nanjing, China) and were housed under specific pathogen-free conditions. Pregnant models of $\mathrm{CBA} / \mathrm{J} \times \mathrm{DBA} / 2 \mathrm{~J}, \mathrm{CBA} /$ $\mathrm{J} \times \mathrm{BALB} / \mathrm{C}$, and $\mathrm{CBA} / \mathrm{J} \times \mathrm{CBA} / \mathrm{J}$ matings were established by co-caging female CBA/J mice with DBA/2J, BALB/c, and $\mathrm{CBA} / \mathrm{J}$ males, respectively. Detection of a vaginal plug was chosen to indicate day 0.5 of gestation (E0.5). ${ }^{11,12}$ Embryonic day E12.5 was chosen as the gestational time to collect uNK cells because the UNK cells are at peak density on day E10 and have not yet begun to decrease in density through apoptosis (which begins on day E13 or E14). ${ }^{13}$ Furthermore, we expected that it would be easier to distinguish healthy embryos from resorbing ones on day E12.5 than at an earlier time point. All animal procedures followed the national animal care guidelines, and associated data were approved for publication by the institutional review board of Shanghai Jiaotong University.

\section{Purification of uNK Cells}

Cell purification was performed by means of MACS. ${ }^{11,12}$ Briefly, hysterolaparotomy was performed on day E12.5 to collect embryo-depleted placentas from CBA/ $\mathrm{J} \times \mathrm{DBA} / 2 \mathrm{~J}$ and $\mathrm{CBA} / \mathrm{J} \times \mathrm{BALB} / \mathrm{c}$ matings. The uterine horns were opened longitudinally, and the fetoplacental unit was separated easily from the uterine implantation sites. The whole placental and decidual unit was separated individually from the respective embryo. The pooled placentas and decidua basalis (ie, decidual tissue in implantation sites) were collected into a dish and carefully cut into small pieces, collected in $0.9 \% \mathrm{NaCl}$ solution, and subsequently filtered through a nylon mesh (50- $\mu \mathrm{m}$ pore size) to obtain a single cell suspension. Mononuclear cells were obtained by centrifuging of the single cell suspension using a Ficoll-Hipaque density column. Any red blood cells that contaminated the single cell suspension were eliminated by incubation with red blood cell lysis buffer (eBioscience Inc., San Diego, CA) two times at $37^{\circ} \mathrm{C}$. Subsequently, NK cells were isolated using magnetic bead-conjugated antimouse CD49b monoclonal antibody, and CD49b ${ }^{+}$cells were purified by means of Mini MACS columns (Miltenyi Biotec Inc., Auburn, CA), ${ }^{11,12}$ where CD49b was used as a common marker for murine NK cells. ${ }^{14}$ The purity of the MACSisolated NK cells routinely exceeded $95 \%$ as determined using flow cytometry. ${ }^{12,15}$

\section{Flow Cytometry}

Uterine NK cells were stained with phosphatidylethanolamine (PE)-conjugated antimouse CD49b (BioLegend, San Diego, CA) and rabbit anti-stathmin-1 (catalog number ab52906; Abcam, Cambridge, England) antibodies, followed by fluorescein isothiocyanate (FITC)-conjugated antirabbit IgG (Molecular Probes Inc., Eugene, OR). The percentage of stathmin- $1^{+}$cells in the CD49b ${ }^{+}$ NK cell population was determined by using a flow cytometer (FACSAria; BD Biosciences, Franklin Lakes, $\mathrm{NJ}) .{ }^{11}$ Cells were stained with PE-conjugated antimouse CD49b and FITC-conjugated antimouse CD122 antibodies (both from BioLegend) to determine the percentage of $\mathrm{CD}_{122^{+}}$cells in the CD49b ${ }^{+}$population. Isotype controls were established by using isotype control antibodies (BioLegend) to exclude false-positive cells. All the experiments were independently performed six times. ${ }^{16-18}$

\section{Preparation of uNK Cell Lysates}

Uterine NK cells were suspended in a modified radioimmunoprecipitation assay buffer $[50 \mathrm{mmol} / \mathrm{L}$ Tris- $\mathrm{HCl}, \mathrm{pH}$ 7.5, $150 \mathrm{mmol} / \mathrm{L} \mathrm{NaCl}, 1 \%$ Triton X-100 (Roche Diagnostics $\mathrm{GmbH}$, Mannheim, Germany), $1 \mathrm{mmol} / \mathrm{L}$ EDTA, 1 $\mathrm{mmol} / \mathrm{L}$ phenylmethylsulfonyl fluoride, $0.66 \mu \mathrm{g} / \mathrm{ml}$ of aprotinin, $0.5 \mu \mathrm{g} / \mathrm{ml}$ of leupeptin, $1 \mu \mathrm{g} / \mathrm{ml}$ of pepstatin, 1 $\mathrm{mmol} / \mathrm{L} \mathrm{Na}_{3} \mathrm{VO}_{4}$, and $1 \mathrm{mmol} / \mathrm{L} \mathrm{NaF]}$ and were sonicated three times for 5 seconds each. The cell lysates were centrifuged at $14,000 \times g$ for 15 minutes at $4^{\circ} \mathrm{C}$. The supernatants were collected, and their protein concen- 
trations were measured by using the Bradford assay (BioRad Laboratories, Hercules, CA). ${ }^{19,20}$

\section{Two-Dimensional Gel Electrophoresis}

The 2-DE was performed according to the manufacturer's instructions. Samples were loaded onto linear immobilized $\mathrm{pH}$ gradient (IPG) strips (IPGstrip, $\mathrm{pH} 4-7 \mathrm{~L}, 180 \times$ $3 \times 0.5 \mathrm{~mm}$; Amersham Biosciences, Piscataway, NJ). Briefly, 1-mg protein samples were diluted to $350 \mu \mathrm{L}$ with a rehydration solution $[7 \mathrm{~mol} / \mathrm{L}$ urea, $2 \mathrm{~mol} / \mathrm{L}$ thiourea, $2 \%$ 3-([3-Cholamidopropyl]dimethylammonio)-I propanesulfonate, $18 \mathrm{mmol} / \mathrm{L}$ dithiothreitol, $0.5 \%(\mathrm{v} / \mathrm{v}) \mathrm{pH} 4-7$ IPG buffer, and trace bromophenol blue] and were applied to the IPG strips with 14 hours of rehydration at $30 \mathrm{~V}$. The proteins were successively focused for 1 hour at $500 \mathrm{~V}, 1$ hour at $1000 \mathrm{~V}$, and 5 hours at $8000 \mathrm{~V}$ for a total of 41,920 $\checkmark$ hours on an IPGphor (Amersham Biosciences). The focused IPG strips were equilibrated for 15 minutes in solution (6 mol/L urea, $2 \%$ SDS, $30 \%$ glycerol, 50 mmol/L Tris- $\mathrm{HCl}, \mathrm{pH} 8.8$, and $1 \%$ dithiothreitol) and then for an additional 15 minutes in the same solution containing $2.5 \%$ iodoacetamide instead of dithiothreitol. After equilibration, SDS-polyacrylamide gel electrophoresis was performed at $10^{\circ} \mathrm{C}$ on $10 \%$ SDS slab gels using the Ettan DALT II system (Amersham Biosciences) with the IPG strips sealed on the top of the gels with $0.5 \%$ agarose. An SDS-polyacrylamide gel electrophoresis was performed at a constant power of $2 \mathrm{~W} / \mathrm{gel}$ for 30 minutes and then switched to $12 \mathrm{~W} / \mathrm{gel}$ until the bromophenol blue marker reached the bottom of the gel. Finally, the blue silver staining method (a modified Neuhoff's colloidal Coomassie Blue G-250 stain) was used to visualize the protein spots in the 2-DE gels. ${ }^{17,20}$

\section{2-DE Image Data Analysis}

Stained 2-DE gels were scanned using LabScan software and ImageScanner (Amersham Biosciences) at a solution of $300 \mathrm{dpi}$. Spot-intensity calibration, spot detection, matching, 1-D calibration, and establishment of an average gel were performed using the PDQuest System (BioRad Laboratories). The theoretical molecular weight and $\mathrm{pl}$ value of the identified protein spots were calculated according to algorithms included in the PDQuest analysis software package. Significant differences in the protein expression levels were determined using the $t$-test, with significance defined at $P<0.05 .{ }^{17,20}$

\section{Preparation of Protein Spots}

Protein spots were excised from the preparative gels and were placed into a 96-well microtiter plate. Proteins were digested in gel as previously described. ${ }^{17,20}$ The gel spots were destained using destaining solution [200 $\mathrm{mmol} / \mathrm{L} \mathrm{NH}_{4} \mathrm{HCO}_{3}$ and $100 \%$ acetonitrile (1:1)] for 20 minutes at room temperature. Gel spots were washed twice with deionized water, shrunk by dehydration in acetonitrile solution, and dried in a vacuum centrifuge. Samples were then swollen in a digestion buffer $(20 \mathrm{mmol} / \mathrm{L}$ ammonium bicarbonate and $12.5 \mathrm{ng} / \mu \mathrm{L}$ of trypsin) (Sig-
ma-Aldrich, St. Louis, MO) for 30 minutes at $4^{\circ} \mathrm{C}$. The gels were then digested for 12 hours at $37^{\circ} \mathrm{C}$. Tryptic peptides were extracted twice from the gel slices by sonication for 15 minutes in a $0.1 \%$ trifluoroacetic acid $/ 50 \%$ acetonitrile solution. The supernatants were collected and dried to a pellet in a high-purity nitrogen flow. Peptides were eluted with $0.7 \mu \mathrm{L}$ of $\alpha$-cyano-4-hydroxycinnamic acid matrix solution and were loaded onto a stainless steel target with 192 wells (Applied Biosystems, Framingham, MA). 17,20

\section{Mass Spectrometry}

Samples were air-dried and then were analyzed by using the Voyager System 4700 matrix-assisted laser desorption/ionization-time of flight-time of flight mass spectrometer (Applied Biosystems). ${ }^{17,20}$

\section{Protein Identification}

Known contaminating peaks (eg, keratin and autoproteolysis peaks) were removed before the database search. Spectra were processed and analyzed using a GPS Explorer (Applied Biosystems). Mascot software (Matrix Science, London, England) was used to search for peptide mass fingerprints and MS/MS data in the NCBInr database. Protein scores by Mascot search analysis that were $>63$ were considered significant $(P<0.05) .{ }^{17,20}$

\section{Western Blotting Analysis}

Tissue aliquots were homogenized to powder using liquid nitrogen and then were dissolved in lysis buffer [150 $\mathrm{mmol} / \mathrm{L} \mathrm{NaCl}, 50 \mathrm{mmol} / \mathrm{L}$ Tris-Cl, $\mathrm{pH}$ 8.0, 0.1\% Nonidet P-40 (Caledon Laboratories Ltd., Georgetown, Ontario, Canada), $1 \mathrm{mmol} / \mathrm{L}$ phenylmethylsulfonyl fluoride, 25 $\mu \mathrm{g} / \mathrm{ml}$ of aprotinin, and $25 \mu \mathrm{g} / \mathrm{ml}$ of leupeptin], vortexed, and incubated at room temperature for 2 hours. The mixture was centrifuged at $20,644 \times \mathrm{g}$ for 30 minutes at $4^{\circ} \mathrm{C}$, and the supernatant was used as the total protein solution. The lysate concentration was assayed using the Bradford assay.

Western blotting analysis was performed as previously described. ${ }^{17,20}$ Briefly, $100 \mu \mathrm{g}$ of total protein was separated on a $12 \%$ SDS-polyacrylamide gel electrophoresis gel before being transferred onto a nitrocellulose membrane. After blocking with 5\% milk in Tris-buffered saline/ $0.2 \%$ Tween 20 for 1 hour at room temperature, the membrane was incubated with rabbit antimouse stathmin-1 antibody (1:100 dilution) (Abcam) for 1 hour at room temperature, followed by incubation with horseradish peroxidase-conjugated goat antirabbit IgG secondary antibody (1:10,000 dilution; Amersham Biosciences) for 1 hour at room temperature. Detection of NADPH was used as a loading control. Reactions were visualized using an enhanced chemiluminescence detection system (ECL; Amersham Biosciences). Signals on the blots were visualized using autography. 


\section{Multivision IHC of Placental Tissue in Murine Models}

Placentas together with decidua basalis harvested on day E10.5 from CBA/J×DBA/2J and CBA/J×BALB/C matings (none of which were analyzed by means of 2-DE) were used to measure the distribution of stathmin-1 protein in lectin from Dolichos biflorus agglutinin-positive (DBA-lectin ${ }^{+}$) cells using a multivision $\mathrm{IHC}$ procedure. Paraffin-embedded tissue blocks were cut into 4 - $\mu \mathrm{m}$-thick sections, which were then deparaffinized in xylene and rehydrated in graded alcohol concentrations. Nonspecific binding was further blocked by preincubation with blocking solution for 5 minutes, followed by incubation for 1 hour at $4^{\circ} \mathrm{C}$ with rabbit antimouse stathmin-1 (1:200 dilution) (Cell Signaling Technology Inc., Beverly, MA). Meanwhile, FITC-conjugated DBA-lectin (1:200 dilution) (Sigma-Aldrich) was added onto the section in the dark for 1 hour. The sections were then washed three times with PBS for 5 minutes each and incubated with PE-conjugated antirabbit IgG (1:200 dilution) (Alpha Diagnostic International, San Antonio, TX) for 30 minutes at room temperature in the dark. Then, 4',6-diamidino-2-phenylindole (Invitrogen, San Diego, CA) was used to stain nuclei for 10 minutes in the dark. Negative controls were established using rabbit $\lg$ of the isotype identical to the rabbit antimouse primary antibody in place of the specific primary antibody (Cell Signaling Technology Inc.). ${ }^{21}$

\section{Multivision IHC of Human Decidual Tissue}

First-trimester human decidual tissue was obtained from five normal pregnancies (free of spontaneous abortion history; mean $\pm \mathrm{SD}$ age, $27.5 \pm 2.2$ years; mean $\pm \mathrm{SD}$ gestational age at sampling, $8.2 \pm 1.1$ weeks, terminated for nonmedical reasons) and five miscarriages [maternal history of more than three unexplained recurrent spontaneous abortions (RSAs); mean \pm SD age, $32.4 \pm 3.9$ years; mean \pm SD gestational age at sampling, $8.5 \pm 2.8$ weeks], which were classified as unexplained after the exclusion of maternal anatomical or hormonal abnormalities and paternal or maternal chromosomal abnormalities. All the samples were obtained from Renji Hospital, Shanghai Jiaotong University, with written informed consent from the patients and permission from the research ethics committee of Shanghai Jiaotong University.

To confirm the existence and define the distribution pattern of $\mathrm{CD}_{56}{ }^{+}$stathmin- $1^{-}$and $\mathrm{CD}^{-} 6^{+}$stathmin- $1^{+}$cells in human decidual tissue, paraffin sections were stained with rabbit antihuman stathmin-1 (Abcam) and mouse antihuman CD56 (Lab Vision/NeoMarkers, Fremont, CA) monoclonal antibodies, followed by staining with multivision antirabbit/horseradish peroxidase (horseradish peroxidase/ diaminobenzidine) plus antimouse/alkaline phosphatase polymers (Biolab Science, Beijing, China), according to the manufacturers' instructions. Using this multivision polymer detection system, stathmin- $1^{+}$cells were stained brown, $\mathrm{CD}^{+} 6^{+}$cells were stained red, and double-positive cells were double colored. Nuclei were lightly stained with hematoxylin.

\section{Inhibition of Stathmin-1 in Vivo}

Inhibition of stathmin-1 was performed in CBA/J $\times D B A /$ 2J, CBA/J×BALB/C, and CBA/J $\times C B A / J$ matings by i.p. injection of anti-stathmin-1 antibody (GenScript USA Inc., Piscataway, NJ) on days E4.5, E5.5, and E6.5 (20 $\mu \mathrm{g}$ in $0.2 \mathrm{ml}$ of PBS) once a day. Mice injected with the same volume of rabbit IgG isotype control antibody were used as controls for each group. The percentage of embryo resorption was detected on day E12.5 by using the method described previously herein ( $n=8$ per group).

\section{Statistical Analysis}

Flow cytometry data were analyzed by using Quad statistics. ${ }^{16}$ The resorption rate was compared using the $\chi^{2}$ test, and the cell percentage was compared using the independent-samples $t$-test. Cell percentage results are presented as mean \pm SD. ${ }^{17,18}$ Significance was defined at $P<0.05$.

\section{Results}

\section{The Percentage of Embryo Loss Is Increased in $C B A / J \times D B A / 2 J$ Matings}

The percentage of spontaneously resorbed embryos on day E12.5 was $22.6 \%$ (35 of $155 ; n=16$ ) in CBA/ $\mathrm{J} \times \mathrm{DBA} / 2 \mathrm{~J}$ matings, $7.6 \%$ (13 of $170 ; n=18$ ) in $\mathrm{CBA} /$ JXBALB/C matings, and $7.2 \%$ (8 of $111 ; n=12$ ) in $\mathrm{CBA} / \mathrm{J} \times \mathrm{CBA} / \mathrm{J}$ matings. There was no significant difference between $\mathrm{CBA} / \mathrm{J} \times \mathrm{BALB} / \mathrm{C}$ and $\mathrm{CBA} / \mathrm{J} \times \mathrm{CBA} / \mathrm{J}$ matings in the percentage of embryo loss, whereas the percentage of embryo resorption in $\mathrm{CBA} / \mathrm{J} \times \mathrm{DBA} / 2 \mathrm{~J}$ matings was significantly higher than that in $\mathrm{CBA} / \mathrm{J} \times \mathrm{BALB} / \mathrm{C}$ and $\mathrm{CBA} / \mathrm{J} \times \mathrm{CBA} / \mathrm{J}$ matings $(P<0.01$ for both). The increased resorption rate of $C B A / J \times D B A / 2 J$ matings supports the hypothesis that these mice are prone to spontaneous embryo loss.

\section{Flow Cytometric Analysis of MACS-Purified CD49b ${ }^{+}$Cells}

The mean \pm SD percentage of stathmin- $1^{+}$cells in the $\mathrm{CD}_{49 \mathrm{~b}}{ }^{+} \mathrm{NK}$ cell population was approximately six-fold higher in CBA/JXBALB/c matings $(5.2 \% \pm 1.5 \%)$ than in $\mathrm{CBA} / \mathrm{J} \times \mathrm{DBA} / 2 \mathrm{~J}$ matings $(0.9 \% \pm 0.4 \%)(P<0.01)$, as indicated by flow cytometry (Figure 1).

Two-color flow cytometry revealed that most CD49b+ cells also expressed CD122 molecules in both matings. The mean \pm SD percentage of $\mathrm{CD} 122^{+} \mathrm{CD} 49 \mathrm{~b}^{+}$cells in the $\mathrm{CD}_{49 \mathrm{~b}}{ }^{+}$population was $74.9 \% \pm 11.4 \%$ in $\mathrm{CBA} / \mathrm{J} \times \mathrm{DBA} / 2 \mathrm{~J}$ matings, which was not significantly different from that in $\mathrm{CBA} / \mathrm{J} \times \mathrm{BALB} / \mathrm{c}$ matings $(65.6 \% \pm 8.8 \%)$.

\section{Reduced Stathmin-1 Production in uNK Cells in $C B A / J \times D B A / 2 J$ Matings in 2-DE}

Proteins from two sets of pooled (12 pregnant mice per group) $\mathrm{UNK}$ cell lysates isolated from $\mathrm{CBA} / J \times \mathrm{DBA} / 2 \mathrm{~J}$ 
A

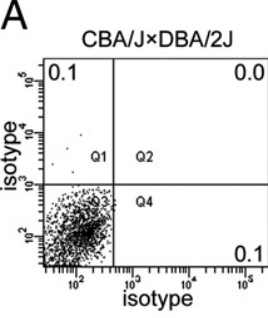

B

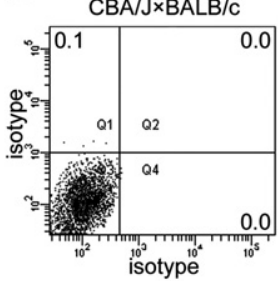

$\mathrm{F}$
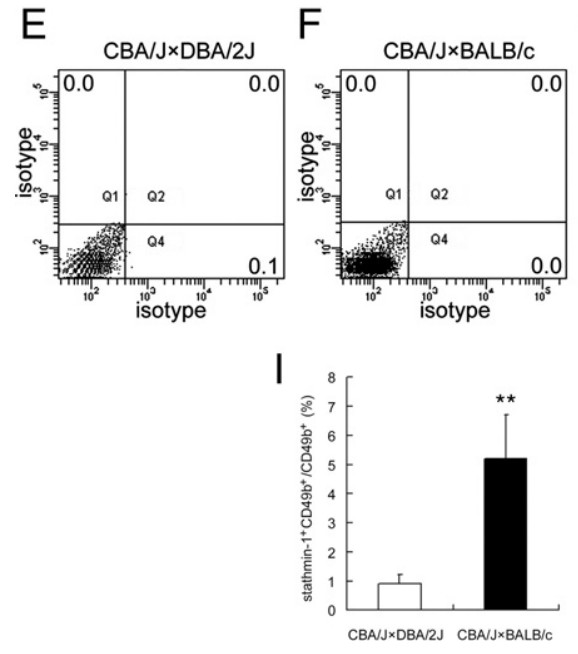

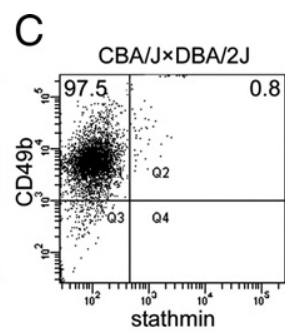

$G$

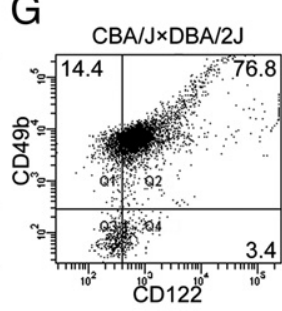

$\mathrm{J}$

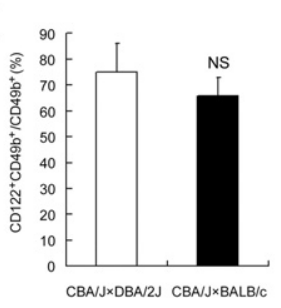

CBA $/ J \times B A L B / C$

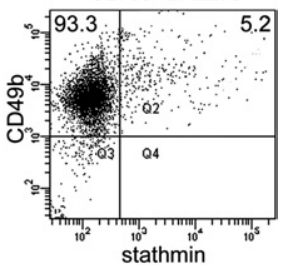

$\mathrm{H}$

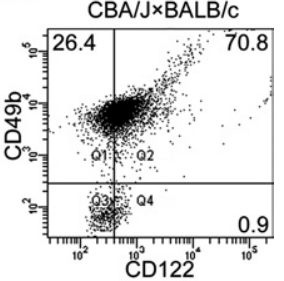

Figure 1. Flow cytometric analysis of stathmin $-1^{+}$and $\mathrm{CD} 122^{+}$cells in uNK cells. $\mathbf{A}-\mathbf{H}$. Representative results derived from cells purified using microbead-conjugated anti-CD $49 \mathrm{~b}$ and a Mini MACS. A, B, E, F: Isotype controls established using cells stained with FITC- and PEconjugated isotype antibodies. C, D: Analysis of stathmin $-1^{+}$cells in the CD $49 \mathrm{~b}^{+}$cell population. The cell percentage is indicated. G, H: Analysis of $\mathrm{CD} 122^{+}$cells in the $\mathrm{CD} 49 \mathrm{~b}^{+}$cell population. I. J: Data summary of flow cytometry. Experiments were independently repeated six times in each group. The mean \pm SD percentage of stath min- $1^{+} \mathrm{CD} 49 \mathrm{~b}^{+}$cells was lower in $\mathrm{CBA}$ $\mathrm{J} \times \mathrm{DBA} / 2 \mathrm{~J}$ mice than in $\mathrm{CBA} / \mathrm{J} \times \mathrm{BALB} / \mathrm{c}$ mice $(0.9 \% \pm 0.4 \%$ versus $5.2 \% \pm 1.5 \%, P<0.01)$. A strong CD122 signal was detected in both mating combinations. The mean $\pm \mathrm{SD}$ percentage of $\mathrm{CD}_{122}{ }^{+} \mathrm{CD} 49 \mathrm{~b}^{+}$cells in the $\mathrm{CD} 49 \mathrm{~b}^{+}$population was $74.9 \% \pm 11.4 \%$ in $\mathrm{CBA} / \mathrm{J} \times \mathrm{DBA} / 2 \mathrm{~J}$ mice and $65.6 \% \pm 8.8 \%$ in $\mathrm{CBA} / \mathrm{J} \times \mathrm{BALB} / \mathrm{c}$ mice, suggesting that most of the MACS-purified CD $49 \mathrm{~b}^{+}$cells also express CD122. Error bars represent SD. ${ }^{* *} P<0.01$. matings and age-matched $\mathrm{CBA} / \mathrm{J} \times \mathrm{BALB} / \mathrm{C}$ matings on day E12.5 were resolved using 2-DE. These experiments were repeated four times under identical experimental conditions and parameters to confirm reproducibility. Well-resolved and reproducible Coomassie Brilliant Blue-stained 2-DE maps from $\mathrm{CBA} / J \times D B A / 2 \mathrm{~J}$ and $\mathrm{CBA} / \mathrm{J} \times \mathrm{BALB} / \mathrm{c}$ matings were obtained. The intensity of the stathmin-1 protein spot derived from CBA/ JXBALB/C matings was approximately four-fold higher than that in CBA/J $\times D B A / 2 J$ matings (mean $\pm \mathrm{SD}, 4.1 \pm$ 0.9-fold; $P<0.01$ ) (Figure 2).

\section{Identification and Quantification of Stathmin-1 Protein Using Matrix-Assisted Laser Desorption/Ionization-Time of Flight-MS}

In the 2-DE analysis described previously herein, differentially expressed protein spots were excised from Coomassie Brilliant Blue-stained gels and were subjected to in-gel digestion with trypsin. An aliquot of the supernatant containing tryptic peptides was analyzed by means of matrix-assisted laser desorption/ionization-time of flighttime of flight-MS/MS, and the Mascot search program software package was used to identify the analyzed protein spots. Proteins receiving a significant score $>63$ $(P<0.05)$ in the Mascot database were ranked as the best hits. Stathmin-1 was one protein that was differentially expressed between the two sets of samples. The protein spot shown in Figure 2 was analyzed using MS and was identified as stathmin-1 (Figure 3). Stathmin-1 received a protein score of 280 , a molecular weight of 17,264 Da, a pl of 5.76, and accession number gi 9789995.
The differential expression of stathmin- 1 was further confirmed by immunoblots using a stathmin-1-specific antibody. The intensity of the stathmin-1 spot in CBA/J $\times B A L B / C$ matings was a mean \pm SD $6.9 \pm 2.2$-fold higher than that in $\mathrm{CBA} / \mathrm{J} \times \mathrm{DBA} / 2 \mathrm{~J}$ matings $\left({ }^{\star \star} P<0.01\right)$ (Figure 4).
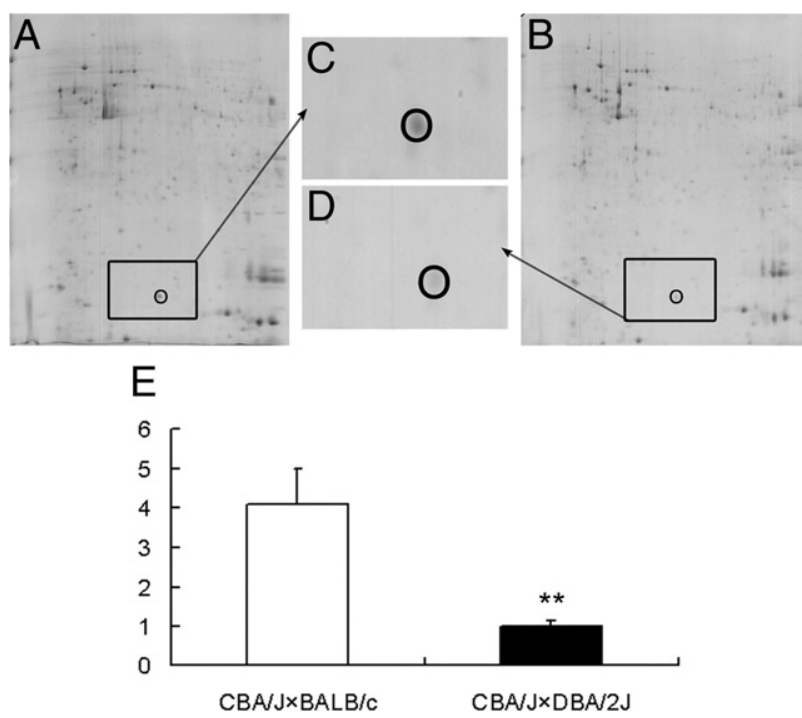

Figure 2. Stathmin-1 expression determined using 2-DE. A-D: Map of uterine lymphocyte lysates from $\mathrm{CBA} / \mathrm{J} \times \mathrm{BALB} / \mathrm{c}$ mice $(\mathbf{A}$ and $\mathbf{C})$ or $\mathrm{CBA}$ $\mathrm{J} \times \mathrm{DBA} / 2 \mathrm{~J}$ mice $(\mathbf{B}$ and $\mathbf{D})$. $\mathbf{C}$ and $\mathbf{D}$ indicate the original magnification of the stathmin- 1 protein spot from $\mathrm{CBA} / \mathrm{J} \times \mathrm{BALB} / \mathrm{C}$ and $\mathrm{CBA} / \mathrm{J} \times \mathrm{DBA} / 2 \mathrm{~J}$ mice, respectively. The density of the stathmin- 1 protein spot from $\mathrm{CBA} / \mathrm{J} \times \mathrm{BALB} / \mathrm{C}$ mice was higher than that from $\mathrm{CBA} / \mathrm{J} \times \mathrm{DBA} / 2 \mathrm{~J}$ mice as observed by the naked eye. E: Mean density as determined using Image-Pro Plus 6.0. The mean density of stathmin- 1 spots in $\mathrm{CBA} / \mathrm{J} \times \mathrm{BALB} / \mathrm{c}$ mice was a mean $\pm \mathrm{SD}$ $4.1 \pm 0.9$-fold higher than that in $\mathrm{CBA} / \mathrm{J} \times \mathrm{DBA} / 2 \mathrm{~J}$ mice $\left({ }^{* *} P<0.01\right)$. Experiments were independently performed four times. Error bars represent SD. 


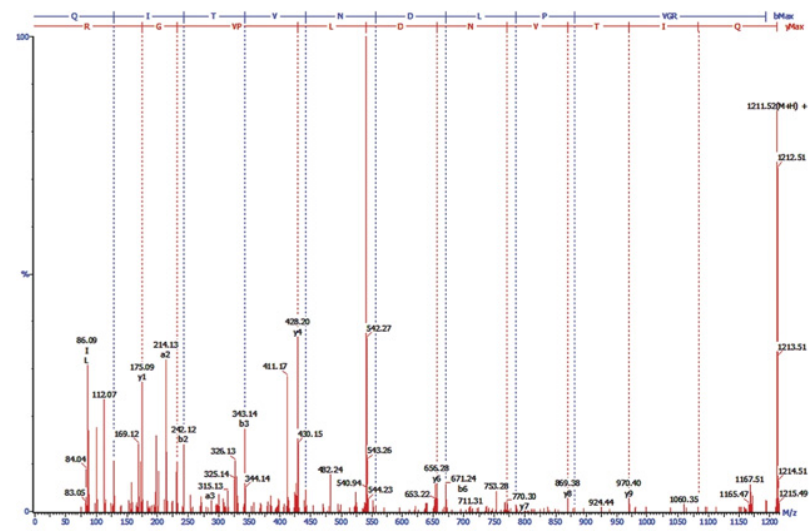

1 MASGNAQIGK SAPDPTATAY YDGAFKEIKL SDYRGKYYYL FFYPLDPTFY 51 CPTRIIAPSD HABDPRKLCC EVLGVSVDSQ PTHLAWINTP RKRGGLGPLN 101 IPLLADYTKS LSQNYGVLKN DEGIAYRGLP IIDAKGVLRQ ITVIDIPYGR 151 SVDEALRIVQ AFQY TD EHGE VCPAGWKPGSD TIKPNVDDS KEYFSKHN

Figure 3. Mass spectrometry of the stathmin-1 spot. MS/MS signals were derived from the parent ion, for which the amino acid sequence, QITVNDLPVGR, was deduced based upon these ions in tandem MS spectrum. MS/MS spectrum of stathmin-1 is shown. Peptide was identified by matrixassisted laser desorption/ionization time of flight/time of flight MS/MS and matched with residues $140-150$ of stathmin-1. Protein sequence of stathmin-1 is shown, and matched MS/MS fragmentation is underlined. The peptide mass fingerprinting and the MS/MS maps of stathmin-1 were combined to confirm the MS results.

\section{Disparate Abundance of Stathmin- $1^{+} D B A$-Lectin ${ }^{+}$ Cells between $C B A / J \times B A L B / C$ and $C B A / J \times D B A / 2 J$ Matings}

As shown in Figure 5, the presence of stathmin- $1^{+} \mathrm{DBA}$ lectin ${ }^{+}$cells was confirmed in CBA/J $\times B A L B / c$ and CBA/ $J \times D B A / 2 J$ matings using multivision IHC. The DBA-lec$\mathrm{tin}^{+}$cells were stained green, stathmin- $1^{+}$cells were stained red, and double-positive cells were yellow in the merged images. Nuclei were stained blue by $4^{\prime}, 6$-diamidino-2-phenylindole.

However, the frequency of stathmin- $1^{+}$DBA-lectin ${ }^{+}$ cells was significantly higher in $\mathrm{CBA} / \mathrm{J} \times \mathrm{BALB} / \mathrm{c}$ matings, whereas DBA-lectin ${ }^{+}$stathmin- $1^{+}$cells were rare in CBA/ $\mathrm{J} \times \mathrm{DBA} / 2 \mathrm{~J}$ matings. As indicated in Figure 5, A-D, DBAlectin ${ }^{+}$cells (green) are more dominant than stathmin- $1^{+}$ cells in both mating combinations. However, red (stathmin-1) is robust in CBA/J $\times B A L B / C$ matings but either absent or faint in $\mathrm{CBA} / \mathrm{J} \times \mathrm{DBA} / 2 \mathrm{~J}$ matings. In the merged images, the relative number of stathmin- $1^{+}$DBA-lectin ${ }^{+}$ cells (yellow) is higher in CBA/J $\times B A L B / C$ matings (Figure $5, A$ and $B$ ) than in $C B A / J \times D B A / 2 J$ matings (Figure $5, C$ and D).

The murine cells positive for DBA-lectin were scattered intensively in decidual basalis tissue and in the mesometrial lymphoid aggregate of pregnancy in both matings, whereas no DBA-lectin ${ }^{+}$cells were observed in placenta tissue (region P) (Figure 5, E and F). ${ }^{22}$

The mean density of stathmin- $1^{+}$DBA-lectin ${ }^{+}$cells was determined using Image-Pro Plus 6.0 (Media Cybernetics Inc., Bethesda, MD). The mean \pm SD density of the doublepositive cells was significantly higher in CBA/J $\times B A L B / C$ matings than in $\mathrm{CBA} / \mathrm{J} \times \mathrm{DBA} / 2 \mathrm{~J}$ matings $(9.6 \pm 5.5$ versus $1.0 \pm 0.9 ; P<0.01$ ) (Figure 5G).

\section{The Distribution Pattern of Stathmin- $1^{+}$Cells in the Human $\mathrm{CD}_{56}{ }^{+}$Cell Population}

The distribution pattern of stathmin- $1^{-} \mathrm{CD}^{-} 6^{+}$and stathmin$1^{+} \mathrm{CD}^{+} 6^{+}$cells was evaluated by means of double-vision $\mathrm{IHC}$. Stathmin- $1^{+} \mathrm{CD} 56^{+}$cells were observed in human decidua from RSA patients (Figure 6, A-D) and those with normal early pregnancy (Figure $6, \mathrm{E}-\mathrm{H}$ ) but were more frequently detected in the latter. Stathmin- $1^{-} \mathrm{CD}_{5}{ }^{+}$and stathmin $-1^{+}$CD56 ${ }^{+}$cells were mainly detected in tissues near blood vessels, whereas stathmin $-1^{+} \mathrm{CD} 56^{+}$cells were seldom found in tissues where there were almost no blood vessels. The mean density of stathmin $-1^{+} \mathrm{CD} 56^{+}$cells was determined using Image-Pro Plus 6.0. The mean \pm SD density of the double-positive cells was significantly higher in normal early pregnancy than in RSA patients (13.6 \pm 7.2 versus $1.0 \pm 0.7 ; P<0.01$ ) (Figure $6 \mathrm{l}$ ).

\section{Effects of Anti-Stathmin-1 Antibody Treatment on Embryo Loss}

The mean $\pm S D$ percentage of embryo resorption was higher in $\mathrm{CBA} / \mathrm{J} \times \mathrm{DBA} / 2 \mathrm{~J}$ matings when stathmin-1 protein was inhibited using a neutralizing antibody (with inhibition: $42.1 \% \pm 21.2 \%$, 32 of 76 ; control: $21.8 \% \pm 12.4 \%, 17$ of 78 ; $P<0.05)$ (Figure 7). The change in the percentage of embryos lost in the CBA/J×BALB/C and CBA/J×CBA/J matings treated with the stathmin-1 neutralizing antibody did not reach statistical significance $(\mathrm{CBA} / \mathrm{J} \times \mathrm{BALB} / \mathrm{C}$, with inhibition: $14.1 \% \pm 10.1 \%, 11$ of 78 ; CBA/J $\times B A L B / c$, control: $8.5 \% \pm 5.4 \%$, 6 of $71 ; \mathrm{CBA} / \mathrm{J} \times \mathrm{CBA} / \mathrm{J}$, with inhibition: $9.9 \% \pm 6.5 \%$, 8 of $75 ; \mathrm{CBA} / \mathrm{J} \times \mathrm{CBA} / \mathrm{J}$, control: $7.3 \% \pm$ $6.5 \%$; 6 of 79 ) (Figure 7 ).

\section{Discussion}

Stathmin is reportedly expressed in the glandular epithelium and stromal cells of human endometrial tissue by cytotrophoblasts and extravillous trophoblasts but not by syncytiotrophoblasts. ${ }^{6}$ When stromal cells isolated from normal endometrial tissues were previously cultured and stimulated to decidualize by progesterone plus estrogen or CAMP, their total and phosphorylated stathmin levels decreased.

A

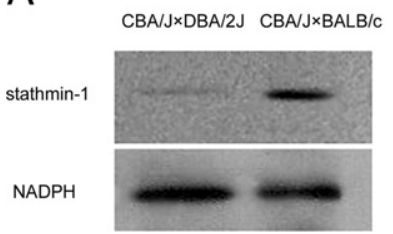

B

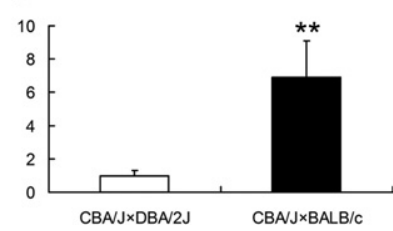

Figure 4. Western blot analysis of stathmin-1 expression in $\mathrm{CBA} / \mathrm{J} \times \mathrm{DBA} / 2 \mathrm{~J}$ and $\mathrm{CBA} / \mathrm{J} \times \mathrm{BALB} / \mathrm{c}$ matings. A: Stathmin-1 expression is significantly downregulated in $\mathrm{CBA} / \mathrm{J} \times \mathrm{DBA} / 2 \mathrm{~J}$ mice compared with $\mathrm{CBA} / \mathrm{J} \times \mathrm{BALB} / \mathrm{c}$ mice NADPH was used as an internal loading control. B: Histogram showing the relative expression level of stathmin- 1 protein in $\mathrm{CBA} / \mathrm{J} \times \mathrm{BALB} / \mathrm{C}$ and $\mathrm{CBA} /$ $\mathrm{J} \times \mathrm{DBA} / 2 \mathrm{~J}$ mice as determined using Image-Pro Plus 6.0. The stathmin-1 protein level is a mean $\pm \mathrm{SD} 6.9 \pm 2.2$-fold higher in $\mathrm{CBA} / \mathrm{J} \times \mathrm{BALB} / \mathrm{c}$ mice than in $\mathrm{CBA} / \mathrm{J} \times \mathrm{DBA} / 2 \mathrm{~J}$ mice as determined using densitometric analysis (** $P<0.01$ ). Experiments were independently repeated four times for each group. Error bars represent SD 


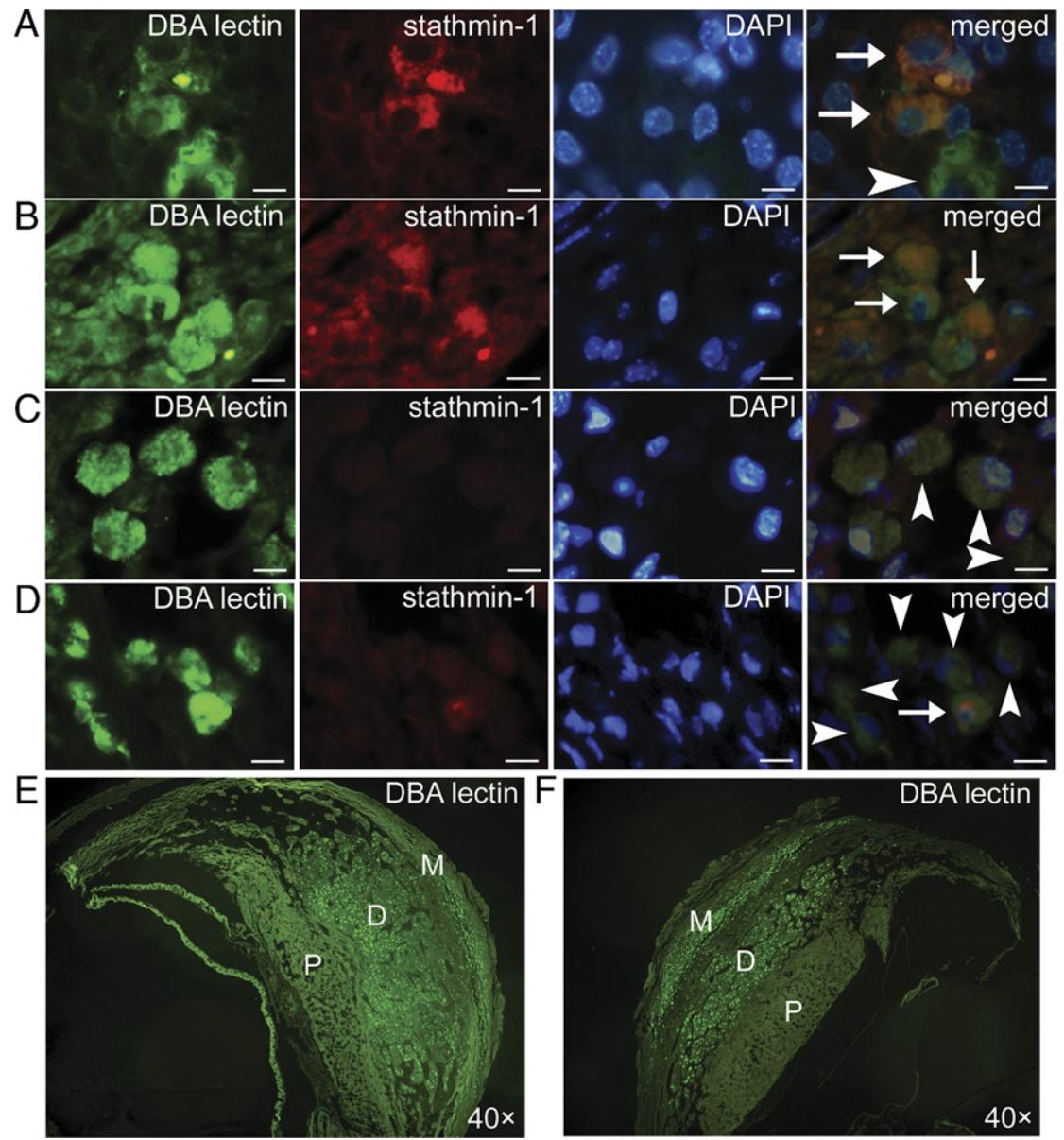

Figure 5. The distribution pattern of stathmin $1^{+}$DBA-lectin ${ }^{+}$cells in murine tissue. In multivision IHC, uNK cells were stained green with FITC-conjugated DBA-lectin, stathmin- ${ }^{+}$cells were indirectly stained red with rabbit antistathmin-1 and PE-conjugated antirabbit IgG, and nuclei were stained blue with DAPI. In the merged images, stathmin- ${ }^{+}$DBA-lectin ${ }^{+}$cells appear yellow or orange (arrows) and stathmin-1 ${ }^{-}$DBA-lectin ${ }^{+}$cells are green (arrowheads). A and B: From $\mathrm{CBA} / \mathrm{J} \times \mathrm{BALB} / \mathrm{c}$ mice. $\mathbf{C}$ and D: From $\mathrm{CBA} / \mathrm{J} \times \mathrm{DBA} / 2 \mathrm{~J}$ mice. $\mathbf{A}$ and $\mathbf{B}$ as well as $\mathbf{C}$ and $\mathbf{D}$ are presented to show reproducibility. Scale bar $=10 \mu \mathrm{m}$. The DBA-lectin cells were dominant in both mating combinations compared with stathmin- $1^{+}$cells and other indicated cell subsets. In the merged images from $\mathrm{CBA} / \mathrm{J} \times \mathrm{DBA} / 2 \mathrm{~J}$ matings, red (stathmin-1) is either absent or faint. In contrast, red (stathmin-1) is robust in the images from CBA $\mathrm{J} \times \mathrm{BALB} / \mathrm{C}$ matings and readily yield yellow and is visible in the presence of green (DBA-lectin). E: From $\mathrm{CBA} / \mathrm{J} \times \mathrm{BALB} / \mathrm{c}$ mice. F: From $\mathrm{CBA}$ $\mathrm{J} \times \mathrm{DBA} / 2 \mathrm{~J}$ mice. Original magnification, $\times 40(\mathbf{E}$ and F). P, placenta; D, decidual basalis; $M$, mesometrial lymphoid aggregate of pregnancy. The DBA-lectin $^{+}$cells were scattered intensively in regions $\mathrm{D}$ and $\mathrm{M}$ in both matings, but no positive cells were found in region P. G: The mean density of stathmin- $1^{+}$DBA-lectin ${ }^{+}$cells as determined using Image-Pro Plus 6.0. Error bars represent $\mathrm{SD} .{ }^{* * *} P<0.01$

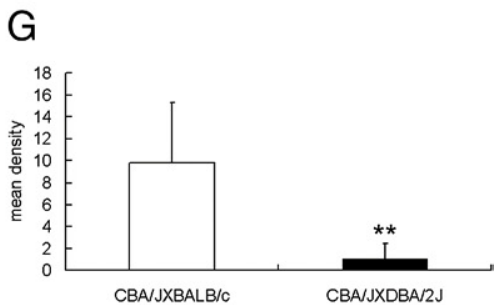

Stathmin silencing in primary stromal cells using small interfering RNA before the cells are exposed to decidualizing agents also markedly suppresses decidualization, suggesting that stathmin may play a key role in decidualization. ${ }^{6}$ Stathmin overexpression favors microtubule destabilization, whereas decreased stathmin expression favors elongated, bundled microtubules and an increased ratio of polymerized to soluble tubulin. ${ }^{23}$ Immunohistochemical analyses using a rat model previously revealed that stathmin-1 is exclusively localized in decidual cells, especially in the primary decidual zone surrounding the embryo with markedly more intense staining on day E9.5 than on day E7.5. On day E14.5, when the endometrial stromal cells have completely differentiated into decidual cells, the staining of decidual cells is faint. ${ }^{7}$ An experiment in the delayed implantation pregnant rat model revealed low uterine stathmin expression that was increased after implantation, which was induced by $17 \beta$-estradiol administration to progesteroneprimed animals. Furthermore, decidualization in the pseudopregnant rat, induced by intrauterine oil infusion, stimulates stathmin expression. Stathmin expression clearly increases in the uterus when stimulated by embryo implantation and decidualization and is believed to play a role in the early stages of pregnancy. ${ }^{8}$

Herein, we demonstrated by using two-color flow cytometry that stathmin-1 is expressed intensively in uNK cells isolated from mouse models. The uNK cells were previously purified by means of MACS and were confirmed to be CD3 ${ }^{-} \mathrm{CD}_{49 \mathrm{~b}}{ }^{+}$cells. ${ }^{11}$ In multivision $\mathrm{IHC}$ using decidual samples from humans and CD56 as a pan marker for human NK cells, the distribution pattern of stathmin- $1^{+}$CD56 ${ }^{+}$ cells was consistent with the reported roles of NK cells in the pregnant uterus. Under physiologic conditions, NK cells are the dominant cell population up to mid-gestation in the pregnant uterus and are believed to participate in blood vessel remodeling. ${ }^{24-26}$ The origin of these NK cells is unclear. A previous study demonstrated that NK cells from extrauterine tissue migrate into the pregnant uterus. ${ }^{26}$ Thus, we conclude that a fraction of the stathmin- $1^{+}$cells are actually uNK cells, which immigrate into the pregnant uterus at the early stages of pregnancy and are involved in the modulation of implantation and decidualization.

The percentage of stathmin- $1^{+}$cells in the uNK cell population was significantly higher in CBA/J $\times B A L B / C$ matings than in abortion-prone CBA/J×DBA/2J matings. In addition, the intensity of stathmin-1 expression was stronger in CBA/ $\mathrm{J} \times \mathrm{BALB} / \mathrm{C}$ matings than in CBA/J×DBA/2J matings, as indicated by 2-DE and Western blot analysis. This differential stathmin-1 expression correlated with the difference in the embryo loss rate, which was lower in CBA/J×BALB/C matings than in $C B A / J \times D B A / 2 J$ matings. Thus, the reduced stathmin-1 production in UNK cells correlates with the increased failure of healthy embryos by $\mathrm{CBA} / \mathrm{J} \times \mathrm{DBA} / 2 \mathrm{~J}$ matings. Furthermore, stathmin-1 inhibition with a neutralizing 
antibody increased the percentage of embryo loss in CBA/ $J \times D B A / 2 J$ matings, but no such trend was observed in $\mathrm{CBA} / \mathrm{J} \times \mathrm{BALB} / \mathrm{C}, \quad \mathrm{CBA} / \mathrm{J} \times \mathrm{CBA} / \mathrm{J}$, or syngeneic $\mathrm{CBA} /$ $J \times C B A / J$ matings. These results suggest that stathmin-1 may be a key regulator in the maintenance of allogeneic pregnancy tolerance, at least in $\mathrm{CBA} / \mathrm{J} \times \mathrm{DBA} / 2 \mathrm{~J}$ matings. In $\mathrm{CBA} / \mathrm{J} \times \mathrm{BALB} / \mathrm{c}$ matings, the increase in embryo resorption after stathmin-1 inhibition did not reach statistical significance. Although the reason for this is unclear, it may be explained by the difference in the UNK cell functional status between CBA/J $\times D B A / 2 J$ and $C B A / J \times B A L B / C$ matings, indicating the presence of a fragile system of stathmin-1-mediated modulation in $\mathrm{CBA} / \mathrm{J} \times \mathrm{DBA} / 2 \mathrm{~J}$ matings.

In multivision $\mathrm{IHC}$, colocalization of stathmin-1 and DBA-lectin was confirmed in murine decidual tissue from both mating combinations. However, the frequency of
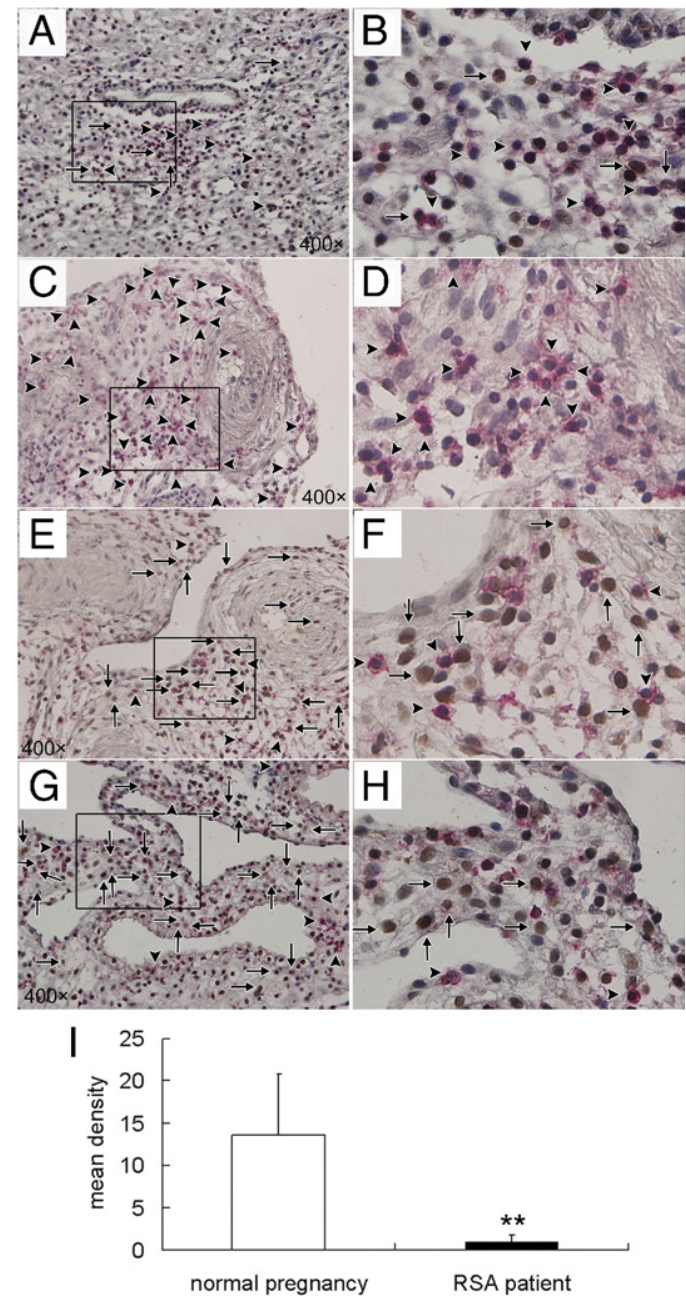

Figure 6. The distribution pattern of stathmin- $1^{+} \mathrm{CD} 56^{+}$cells in human decidua. The distribution pattern of stathmin $-1^{+} \mathrm{CD} 56^{+}$cells was examined by means of double-staining IHC in decidual tissue from RSA patients (A-D) and subjects undergoing healthy elective pregnancy termination $(\mathbf{E}-\mathbf{H})$. Single $\mathrm{CD} 56^{+}$cells are stained red (arrowheads), stathmin $-1^{+} \mathrm{CD} 56^{+}$cells are stained brown (arrows), and nuclei are stained blue with hematoxylin. Original magnification is marked. $\mathbf{B}, \mathbf{D}, \mathbf{F}$, and $\mathbf{H}$ are local magnifications of the regions enclosed with boxes on $\mathbf{A}, \mathbf{C}, \mathbf{E}$, and $\mathbf{G}$, respectively. I: Mean density of stathmin- $1^{+} \mathrm{CD} 56^{+}$cells as determined using Image-Pro Plus 6.0. Error bars represent SD. ${ }^{* *} P<0.01$.

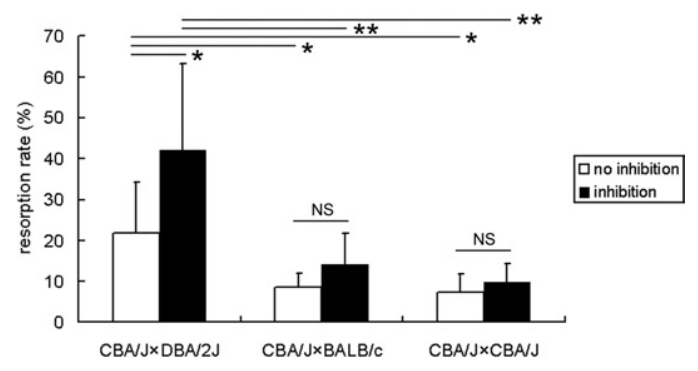

Figure 7. Effect of anti-stathmin-1 antibody treatment on the embryo resorption rate. No inhibition, multiple injections with isotype control antibody; inhibition, multiple injections with neutralizing antibody. In the noinhibition $\mathrm{CBA} / \mathrm{J} \times \mathrm{DBA} / 2 \mathrm{~J}$ group, the percentage of embryo loss was significantly higher than that in the no-inhibition $\mathrm{CBA} / \mathrm{J} \times \mathrm{BALB} / \mathrm{C}$ and $\mathrm{CBA} /$ $\mathrm{J} \times \mathrm{CBA} / \mathrm{J}$ groups, confirming that $\mathrm{CBA} / \mathrm{J} \times \mathrm{DBA} / 2 \mathrm{~J}$ mice are prone to abortion. The percentage of embryo loss was increased after stathmin-1 inhibition in $\mathrm{CBA} / \mathrm{J} \times \mathrm{DBA} / 2 \mathrm{~J}$ mice $\left({ }^{*} P<0.05\right.$, $\left.{ }^{* * *} P<0.01\right)$, but the trend of embryo loss increase did not reach statistical significance in $\mathrm{CBA} / \mathrm{J} \times \mathrm{BALB} / \mathrm{c}$ or $\mathrm{CBA} / \mathrm{J} \times \mathrm{CBA} / \mathrm{J}$ mice. $n=8$ per group. Error bars represent SD.

stathmin- $1^{+}$DBA-lectin ${ }^{+}$cells was significantly higher in $\mathrm{CBA} / \mathrm{J} \times \mathrm{BALB} / \mathrm{c}$ mice than in CBA/J $\times \mathrm{DBA} / 2 \mathrm{~J}$ mice (Figure 5). Stathmin- $1^{+}$DBA-lectin ${ }^{+}$cells were found mainly scattered in the decidua basalis and mesometrial lymphoid aggregate of pregnancy in the murine pregnant uteri. Because the decidua basalis and mesometrial lymphoid aggregate of pregnancy, to some extent, represent the maternal-fetal interface and because more immunopotent cells can infiltrate into these tissues than into other parts of murine placental and decidual tissues, these results suggest that stathmin- $1^{+}$DBA-lectin ${ }^{+} \mathrm{NK}$ cells may be important in the modulation of maternal-fetal cross talk. ${ }^{25,26}$ Similar results were obtained in human decidual tissue. Using CD56 as a pan-NK cell marker for human uNK cells, we found that the frequency of stathmin- $1^{+}$CD56 ${ }^{+}$cells was significantly higher in decidual tissues from normal early pregnancy than in those from spontaneous abortion patients (Figure 6). This suggests that some cases of unexplained spontaneous miscarriage may be attributable to reduced function of UNK cells, including reduced production of stathmin-1 protein in uNK cells. In addition, stathmin $-1^{+} \mathrm{CD}^{+} 6^{+}$cells were found mainly scattered in tissues near blood vessels, suggesting that they may participate in establishment, remodeling, or other functions of the blood vessel system. Stathmin $-1^{+} \mathrm{CD} 56^{+}$cells were less frequently detected in RSA samples, consistent with the results obtained using mouse two-color flow cytometry. Taken together, the results of the present study suggest that a fraction of uNK cells express stathmin-1 molecules and that insufficient stathmin-1 expression in uNK cells may be related to increased embryo loss in abortion-prone mice and some patients with RSA.

In addition to murine uNK cells, CD49b is also expressed by a small fraction of other cell types. ${ }^{13}$ To our knowledge, there is not an ideal marker for murine UNK cells. A cell purification strategy using DBA-lectin and CD122 marker may be more specific for mouse uNK cell purification. ${ }^{22}$ However, microbead-conjugated antibodies for DBA-lectin or CD122 are not commercially available. At present, microbead-conjugated anti-CD49b is used in MACS to purify uNK cells. ${ }^{26}$ In future studies, it 
would be helpful to exclude T cells and other cells by negative selection during UNK cell purification using microbead-conjugated CD3 and other antibodies specific for non-uNK cells that also express CD49b. Because B cells are virtually absent from the pregnant uterus, the possibility of B-cell contamination is small. ${ }^{27} \mathrm{~A}$ recent report suggested that CD122 is a good marker for UNK cells. ${ }^{22}$ To define the percentage of $\mathrm{CD} 122^{+}$cells in the $\mathrm{CD} 49 \mathrm{~b}^{+}$population, we performed two-color flow cytometry using MACS-purified CD49b ${ }^{+}$cells stained with FITC-conjugated anti-CD122 and PE-conjugated antiCD49b antibodies, which showed that most CD49b+ cells were also positive for CD122 in CBA/J $\times D B A / 2 J$ and $\mathrm{CBA} / \mathrm{J} \times \mathrm{BALB} / \mathrm{c}$ mice.

Flow cytometry is quantitative by nature, allowing thousands of cells to be counted and objectively analyzed within minutes. Using two-color flow cytometry with cells stained by FITC-conjugated anti-stathmin-1 and PE-conjugated anti-CD49b, we confirmed that there are doublepositive cells that express stathmin-1 and CD49b and determined the constitutional ratio of these cells. Stathmin-1 expression in CD49b ${ }^{+}$cells was also confirmed using MACS-purified CD49b ${ }^{+}$cells and proteomic assays in the present study (Figures 2 and 3 ).

In summary, decreased stathmin-1 expression in a murine abortion-prone model was confirmed using flow cytometry, 2-DE, MS, and Western blot analysis compared with normal fertile controls. In multivision IHC, colocalization of stathmin-1 and DBA-lectin was confirmed in both matings, but the frequency of stathmin- $1^{+} \mathrm{DBA}$ lectin ${ }^{+}$cells was significantly lower in abortion-prone matings. Inhibition of stathmin-1 significantly boosted embryo resorption rates in mouse models. In patients who experience unexplained spontaneous abortion, the frequency of stathmin- $1^{+} \mathrm{CD} 56^{+}$cells was also significantly lower than in normal pregnancy. These results suggest that adequate stathmin-1 expression in UNK cells may be critical to pregnancy success. In contrast, insufficient stathmin-1 expression may be correlated with pregnancy failure.

\section{Acknowledgment}

We thank Prof. Canrong Ni (Changhai Hospital, Shanghai, China) for his great help in multivision IHC.

\section{References}

1. Curmi PA, Gavet $O$, Charbaut E, Ozon S, Lachkar-Colmerauer $S$, Manceau V, Siavoshian S, Maucuer A, Sobel A: Stathmin and its phosphoprotein family: general properties, biochemical and functional interaction with tubulin. Cell Struct Funct 1999, 24:345-357

2. Rubin $\mathrm{Cl}$, Atweh GF: The role of stathmin in the regulation of the cell cycle. J Cell Biochem 2004, 93:242-250

3. Sobel A: Stathmin: a relay phosphoprotein for multiple signal transduction? Trends Biochem Sci 1991, 16:301-305

4. Brattsand G, Marklund U, Nylander K, Roos G, Gullberg M: Cellcycle-regulated phosphorylation of oncoprotein 18 on ser16, ser25 and ser38. Eur J Biochem 1994, 220:359-368

5. Sobel A, Boutterin MC, Beretta L, Chneiweiss H, Doye V, Peyro-SaintPaul H: Intracellular substrates for extracellular signaling: character- ization of a ubiquitous, neuron-enriched phosphoprotein (stathmin). J Biol Chem 1989, 264:3765-3772

6. Tamura K, Yoshie M, Nishi H, Osakabe Y, Isaka K, Hara T, Kogo H: Expression of stathmin in human uterus and decidualizing endometrial stromal cells. Reproduction 2006, 132:625-636

7. Yoshie M, Tamura K, Kogo H: Differential localization of decidual stathmin during pregnancy in rats. Placenta 2004, 25:449-455

8. Tamura K, Hara T, Yoshie M, Irie S, Sobel A, Kogo H: Enhanced expression of uterine stathmin during the process of implantation and decidualization in rats. Endocrinology 2003, 144:1464-1473

9. Clark DA, Chaouat G, Arck PC, Mittruecker HW, Levy GA: Cytokinedependent abortion in CBA $\times \mathrm{DBA} / 2$ mice is mediated by the procoagulant fgl2 prothombinase. J Immunol 1998, 160:545-549

10. Redecha P, van Rooijen N, Torry D, Girardi G: Pravastatin prevents miscarriages in mice: role of tissue factor in placental and fetal injury. Blood 2009, 113:4101-4109

11. Lin $\mathrm{Y}$, Wang $\mathrm{H}$, Wang W, Zeng S, Zhong Y, Li D-J: Prevention of embryo loss in non-obese diabetic mice using adoptive ITGA2 ${ }^{+}$ISG20 ${ }^{+}$natural killer-cell transfer. Reproduction 2009, 137:943-955

12. Lin $Y$, Zhong $Y$, Shen W, Chen Y, Shi J, Di J, Zeng S, Saito S: TSLPinduced placental DC activation and IL-10+ ${ }^{+} \mathrm{NK}$ cell expansion: comparative study based on BALB/C×C57BL/6 and NOD/SCID $\times C 57 B L / 6$ pregnant models. Clin Immunol 2008, 126:104-117

13. Barber EM, Pollard JW: The uterine NK cell population requires IL-15 but these cells are not required for pregnancy nor the resolution of a Listeria monocytogenes infection. J Immunol 2003, 171:37-46

14. Arase H, Saito T, Phillips JH, Lanier LL: The mouse NK cell-associated antigen recognized by DX5 monoclonal antibody is CD49b ( $\alpha 2$ integrin, very late antigen-2). J Immunol 2001, 167:1141-1144

15. Lin Y, Zhong Y, Saito S, Chen Y, Shen W, Di J, Zeng S: Characterization of natural killer cells in nonobese diabetic/severely compromised immunodeficient mice during pregnancy. Fertil Steril 2009, 91:2676-2686

16. Lin Y, Liang Z, Chen Y, Zeng Y: TLR3-involved modulation of pregnancy tolerance in double-stranded RNA-stimulated NOD/SCID mice. J Immunol 2006, 176:4147-4154

17. Li C, Xiao Z, Chen Z, Zhang X, Li J, Wu X, Li X, Yi H, Li M, Zhu G, Liang $S$ : Proteome analysis of human lung squamous carcinoma. Proteomics 2006, 6:547-558

18. Shen J, Pavone A, Mikulec C, Hensley SC, Traner A, Chang TK, Person MD, Fischer SM: Protein expression profiles in the epidermis of cyclooxygenase-2 transgenic mice by 2-dimensional gel electrophoresis and mass spectrometry. J Proteome Res 2007, 6:273-286

19. DiGiovanni J, Bol DK, Wilker E, Beltran L, Carbajal S, Moats S, Ramirez A, Jorcano J, Kiguchi K: Constitutive expression of insulinlike growth factor- 1 in epidermal basal cells of transgenic mice leads to spontaneous tumor promotion. Cancer Res 2000, 60:1561-1570

20. Li C, Wang W, Wang H, Zhong Y, Di J, Lin Y: Proteomic analysis of proteins differentially expressed in uterine lymphocytes obtained from wild-type and NOD mice. J Cell Biochem 2009, 108:447-457

21. Lin $\mathrm{Y}$, Zeng $\mathrm{Y}$, Di J, Zeng S: Murine $\mathrm{CD} 20 \mathrm{O}^{+} \mathrm{CK} 7^{+}$trophoblasts in a poly (I: c)-induced embryo resorption model. Reproduction 2005, 130:529-537

22. Yadi H, Burke S, Madeja Z, Hemberger M, Moffett A, Colucci F: Unique receptor repertoire in mouse uterine NK cells. J Immunol 2008, 181:6140-6147

23. Alli E, Yang J-M, Ford JM, Hait WN: Reversal of stathmin-mediated resistance to paclitaxel and vinblastine in human breast carcinoma cells. Mol Pharmacol 2007, 71:1233-1240

24. Lin Y, Chen Y, Zeng Y, Wang T, Zeng S: Lymphocyte phenotyping and NK cell activity analysis in pregnant NOD/SCID mice. J Reprod Immunol 2005, 68:39-51

25. Croy BA, Chantakru S, Esadeg S, Ashkar AA, Wei Q: Decidual natural killer cells: key regulators of placental development. J Reprod Immunol 2002, 57:151-168

26. Wang W, Lin Y, Zeng S, Li D-J: Improvement of fertility with adoptive $\mathrm{CD}^{+} 5^{+}$natural killer cell transfer in sub-fertile NOD mice. Reprod BioMed Online 2009, 18:95-103

27. von Rango U, Classen-Linke I, Kertschanska S, Kemp B, Beier HM: Effects of trophoblast invasion on the distribution of leukocytes in uterine and tubal implantation sites. Fertil Steril 2001, 76:116-124 